Int. J. Dev. Biol. 50: 575-579 (2006)

doi: $10.1387 / \mathrm{ijdb} .062141$ as

Developmental Expression Pattern

\title{
Developmental expression of Shisa-2 in Xenopus laevis
}

\author{
ANA-CRISTINA SILVA ${ }^{1,2}$, MÁRIO FILIPE ${ }^{1}$, MARTA VITORINO2 ${ }^{2}$, HERBERT STEINBEISSER ${ }^{3}$ \\ and JOSÉ-ANTÓNIO BELO*,1,2 \\ ${ }^{1}$ Instituto Gulbenkian de Ciência, Oeiras, Portugal, ${ }^{2}$ Centro de Biomedicina Molecular e Estrutural, Universidade do Algarve, Faro, \\ Portugal and ${ }^{3}$ Institute of Human Genetics, University of Heidelberg, Heidelberg, Germany
}

\begin{abstract}
Shisa is an antagonist of Wnt and FGF signaling, that functions cell autonomously in the endoplasmic reticulum (ER) to inhibit the post-translational maturation of Wnt and FGF receptors. In this paper we report the isolation of a second Xenopus shisa gene (Xshisa-2). Xenopus Shisa-2 shows $30.7 \%$ identity to Xshisa. RT-PCR analysis indicated that Xshisa-2 mRNA is present throughout early development and shows an increased expression during neurula and tailbud stages. At neurula stages Xenopus shisa-2 is initially expressed in the presomitic paraxial mesoderm and later in the developing somites. The expression profiles and pattern of $X$ shisa and Xshisa-2 differ significantly. During gastrulation only Xshisa mRNA is present in the SpemannMangold organizer and later on becomes restricted to the neuroectoderm and the prechordal plate.
\end{abstract}

KEY WORDS: Xenopus, shisa, presomitic mesoderm, somite

Secreted growth factors of the Wnt and Fibroblast growth factor (FGF) families have an essential role in vertebrate development (Logan and Nusse, 2004; Böttcher and Niehrs, 2005). However, Wnt activities need to be inhibited for the correct development of the head and heart (Glinka et al., 1997; Marvin et al., 2001; Schneider and Mercola, 2001). The head formation promoting factors Dickkopf (Dkk) and Cerberus are secreted Wnt antagonists that regulate this signaling pathway in the extracellular space (Glinka et al., 1998; Piccolo et al., 1999; Mukhopadhyay et al., 2001; Silva et al., 2003). Shisa, a recently identified protein has been shown to inhibit Wnt as well as FGF signaling in a cell autonomous manner. It binds to the immature form of Frizzled and the FGF receptors in the ER and prevents the post-translational modifications necessary for their function (Yamamoto et. al., 2005).

FGF signaling is critical for specification of the paraxial mesoderm identity (Pourquié, 2001). In mutant mice for FGF8 and FGFR1, no paraxial mesoderm (PM) is formed (Deng et al., 1994; Yamaguchi et al., 1994; Sun et al., 1999). Additionally, studies in Xenopus have shown that eFGF is able to induce XmyoD expression in the mesoderm and specifies the myogenic cells (Fisher et al., 2002). Interestingly, fgfo expressed in the caudal presomitic mesoderm (PSM) was recently shown to inhibit myogenesis (Dubrulle et al., 2001). Wnts were also shown to be involved in the initial steps of myogenesis in mammals (Cossu and Borello, 1999). In Xenopus embryos, injection of Xwnt8RNA leads to an enlargement of the PM territory (Christian \& Moon 1993), whereas injection of dominant-negative Xwnt8impairs the formation of the somitic territory (Hoppler et al., 1996). In higher vertebrates, Wnt3a plays a critical role in maintaining the PM fate in the posterior somites (Takada et al., 1994) and like Fgf8, Wnt3a gradients are also important in controlling segmentation in the PSM (Aulehla et al., 2003). In this paper we report the isolation of Xshisa-2, an ortholog of the mouse shisaand describe its expression during Xenopus laevis embryogenesis. The expression pattern of this gene suggests that it may regulate the activities of Wnts and FGFs during Xenopus somitogenesis.

We have carried out a screening for differentially expressed genes in the mouse Anterior Visceral Endoderm (AVE; Filipe et al., unpublished results). One of the genes identified in the screen was previously named as mouse anterodistally expressed gene2 (GenBank Acc. NM_145463). Through a BLAST search using this gene as query, we have identified two potential Xenopus homologs. One of these homologs was recently reported by Yamamoto et. al., (2005) as shisa. The other homolog, here designated as Xenopus shisa-2(Xshisa-2), has been reported as three EST sequences (GenBank accession no. BC077953, CF286494 and BJ042155). The EST BJ042155 was obtained from NIBB (clone XL050n07; http://xenopus.nibb.ac.jp/) and the insert was completely sequenced. When compared with mouse

Abbreviations used in this paper: AVE, Anterior Visceral Endoderm; CRD, cysteine-rich domains; Dkk, Dickkopf; ER, endoplasmic reticulum; FGF, Fibroblast growth factor; FGFR, Fibroblast growth factor receptor; PM, paraxial mesoderm; PAPC, Paraxial protocadherin; PSM, presomitic mesoderm; TBD, tailbud domain; Xshisa-2, Xenopus shisa-2.

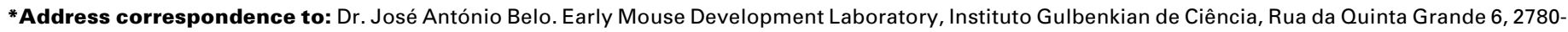
156 Oeiras, Portugal. Fax: +3512-1440-7970. e-mail: jbelo@igc.gulbenkian.pt 
A
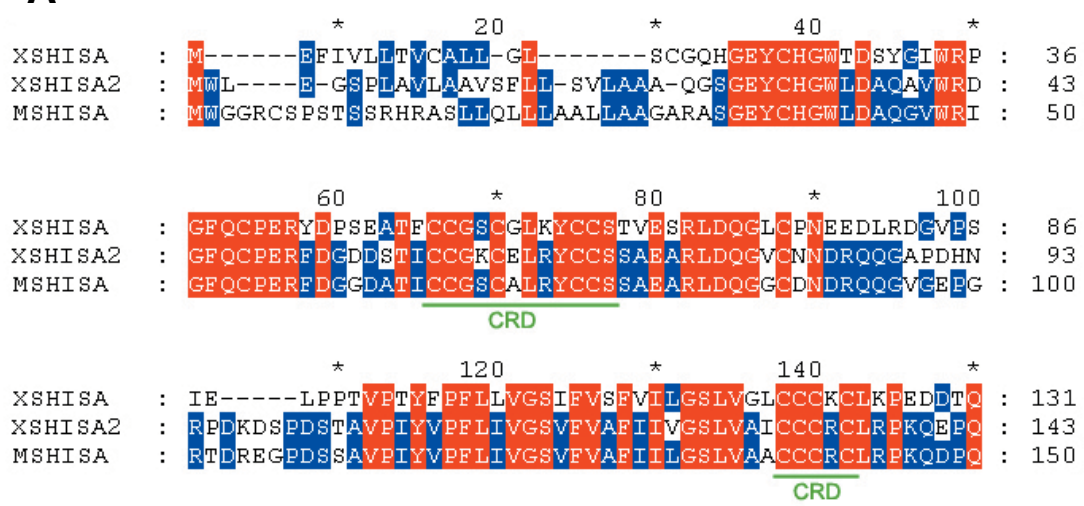

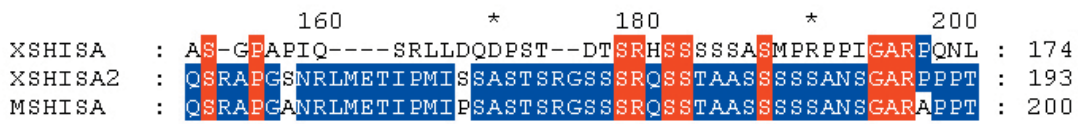

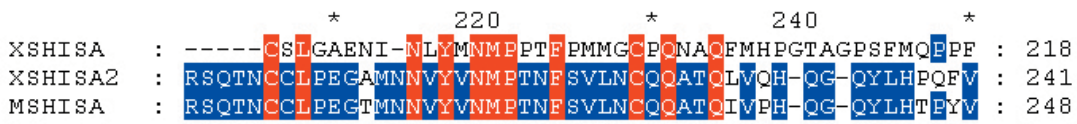

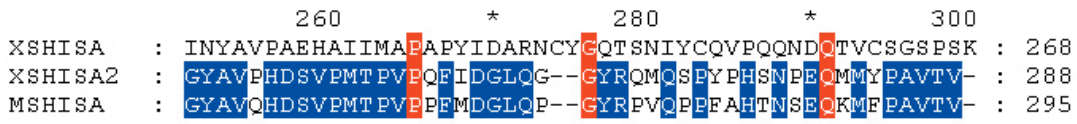

$\begin{array}{llllr}\text { XSHISA } & \text { C } & : & 269 \\ \text { XSHISA2 } & : & - & -\end{array}$

XSHISA2 : $\quad-: \quad-$

MSHISA $\quad:-\quad:-$

\section{B}

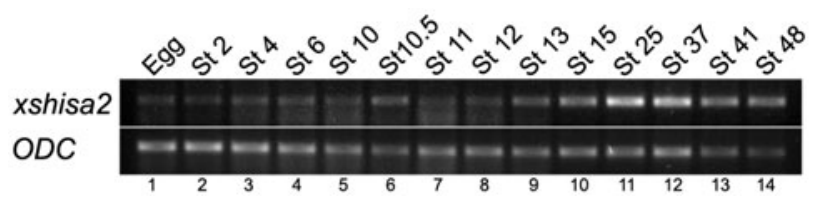

shisa, the sequence obtained from $\mathrm{BC} 077953$ shows homology to the 5' of the mRNA where as BJ042155 shows homology to the 3 ' of the mRNA sequence. These two ESTs show partial overlapping, indicating that the ORF of Shisa-2 could be obtained from these two ESTs. When the combined sequences from these two ESTs were subjected to bioinformatic analysis, a putative open reading frame was obtained. After cloning of the full-length cDNA,
Fig. 1. Sequence alignment of Shisa family members and temporal expression of Xshisa-2 during Xenopus development. (A) Comparison of the predicted amino acid sequence of X. laevis Shisa-2 with X. laevis Shisa and mouse Shisa. Xshisa-2 shares $76.9 \%$ of identity (positives - $84.4 \%$ ) with mShisa-2 and $30.7 \%$ identity (positives - 46.3\%) with Xshisa. Identical amino acids among all are shaded red while identical amino acids in only two sequences are shaded blue. The absence of residues at the corresponding region is indicated by dashes. The two conserved cysteine-rich domains (CRD) are shown in green. The GenBank accession number for $X$. laevis Shisa-2 is DQ342341. (B) Temporal expression pattern of Xenopus Shisa-2 by RT-PCR analysis. RT-PCR was performed with total RNA from different developmental stages. Xshisa-2 transcripts are present maternally at very low levels, increase in the beginning of neurulation and continue to be expressed during early development. Stages are indicated on top. ODC was used as a loading control.

we observed that this gene, Xenopus shisa-2 (GenBank accession no. DQ342341) contains an open reading frame of 867 nucleotides encoding a 288 amino acid protein with a predicted molecular mass of $31.1 \mathrm{kDa}$. Similarly to Xenopus Shisa, Shisa- 2 contains a signal peptide, two conserved cysteine-rich domains (CRD) in the amino-terminal half and a putative transmembrane domain $\mathrm{N}$ terminally to the second CRD. The predicted amino acid sequence of $X$ shisa-2 has close similarity to $X$ shisa (Identity $=30.7 \%$, Positives $=46.3 \%$; Fig. 1A). Comparison of Xenopus Shisa and Shisa-2 sequences with that of mouse Shisa reveals higher conservation between $X$ shisa-2 and mouse Shisa $(\mathrm{I}=76.9 \%, \mathrm{P}=84.4 \%)$ than between $X$ shisa and mouse Shisa $(I=31.9 \%, P=45.2 \%$; Fig. $1 A)$, suggesting that $X$ shisa- 2 is the true ortholog of the previously described mouse protein.

The temporal expression of Xshisa-2 was analyzed by RT-PCR using total RNAs isolated from different developmental stages (Fig. 1B). Transcripts encoding Xshisa 2 are present in all stages analyzed (from mature oocyte until stage 48) and its expression is upregulated in neurula and early tailbud stages.

The spatial expression of Xshisa-2 during early Xenopus development was characterized by whole-mount in situhybridization. Xshisa-2 transcripts were not detectable by in situhybridization until gastrulation. At late gastrula/early neurula stages Xshisa
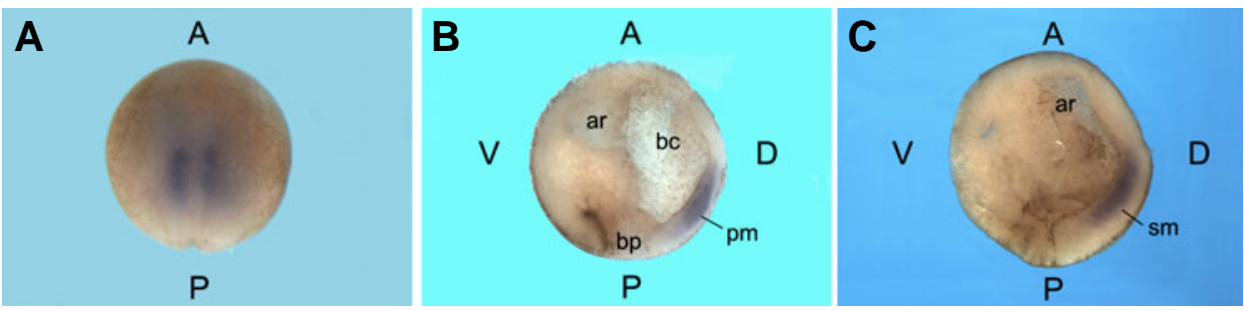

Fig. 2. Xshisa-2 expression in the end of gastrulation and beginning of neurulation. Whole mount in situ hybridization with a Shisa-2 DIG-labeled antisense RNA probe was performed on embryos at the end of gastrulation and beginning of neurulation. (A) Xshisa-2 expression by the end of gastrulation (st 13) is restricted to two narrow stripes on the dorsal side of the embryo, but not in the notochord. Posterior dorsal view. (B-C) Hemisections of stage 12 and 14 embryos show that Xshisa2 mRNA is restricted to the posterior portion of the paraxial mesoderm. Hemisections with dorsal to the right. A, anterior; $P$, posterior; $D$, dorsal; $V$, ventral; ar, archenteron; bc, blastocoel; pm, paraxial mesoderm; sm, somitic mesoderm. 

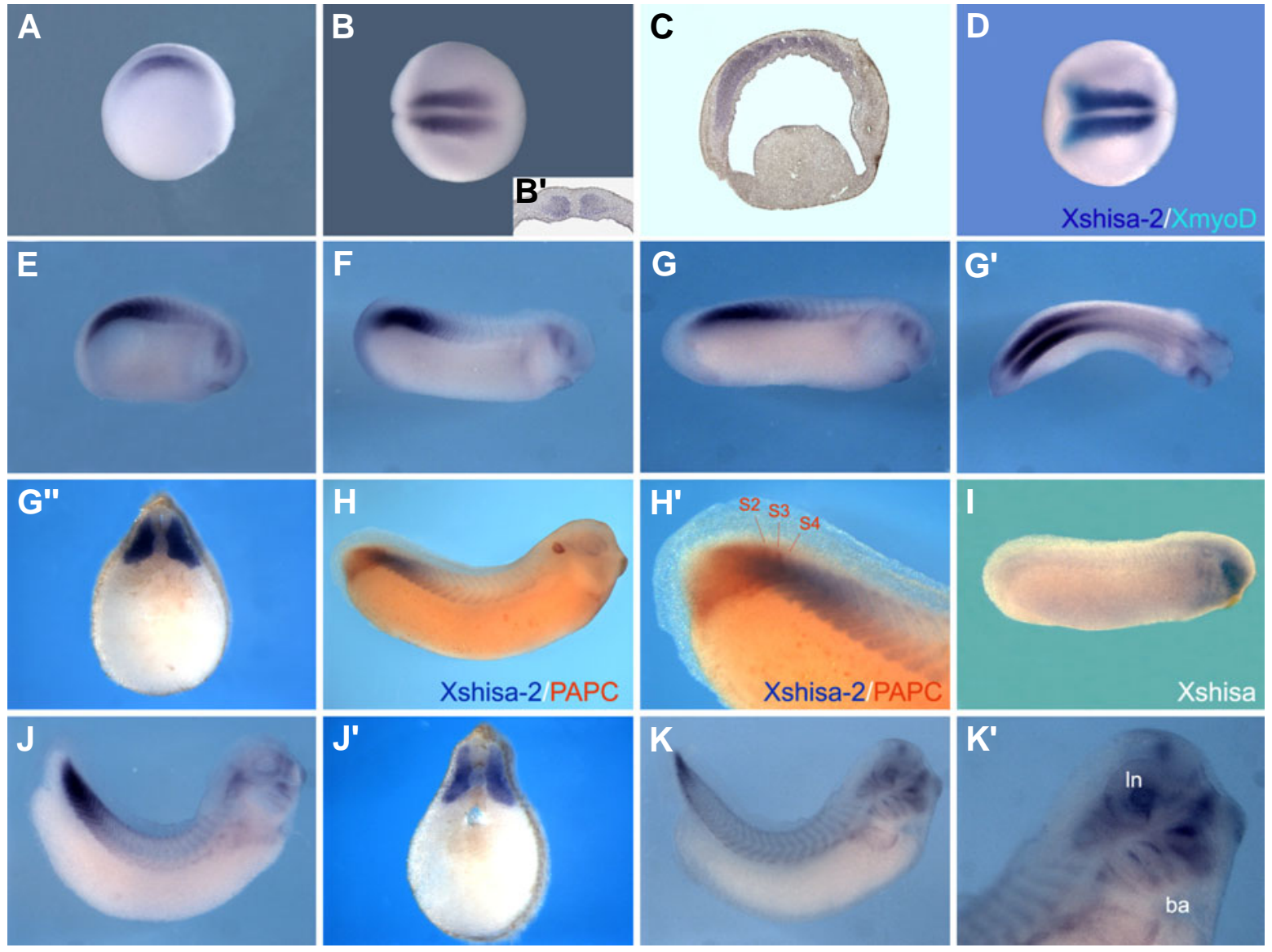

Fig. 3. Expression pattern of Xshisa-2 during tailbud stages. From early tailbud stage onward, a dynamic pattern is observed in the forming somites. (A-B) At stage 18, Xshisa-2 becomes progressively reduced in the anterior paraxial mesoderm. (B') Transverse section showing Xshisa-2 expression in the entire somite region. (C) Parasagittal section of a stage 18 embryo. (D) Double whole mount in situ hybridization with Xshisa-2 DIGlabeled antisense RNA probe and XmyoD fluo-labelled antisense RNA probe. The expression domain of XmyoD extends more posteriorly than the Xshisa-2 expression domain. (E-H,J-K) Expression of Xshisa-2 is stronger in the presomitic mesoderm and decreases as somites form. Transverse sections through the trunk region of stage $27\left(\mathbf{G}^{\prime \prime}\right)$ and $30\left(\mathbf{J}^{\prime}\right)$ embryos show Xshisa-2 expression in the entire somite. $\left(\mathbf{H}, \mathbf{H}^{\prime}\right)$ Double whole mount in situ hybridization with Xshisa-2 and PAPC shows that Xshisa-2 is not expressed in the unsegmented region of the presomitic mesoderm. (I) Whole mount in situ hybridization with Xshisa shows expression restricted to the head region, a distinct expression pattern than the one observed for Xshisa-2. (K') A complex expression pattern is also observed in the head, including the lens (In) and branchial arches (ba). (A, C, E-G, H-J, K, K') Lateral view. (B, D, G'). Dorsal view. All embryos are oriented with anterior to the right.

2 is restricted to two stripes in the dorsal side but excluded from the dorsal midline (Fig. 2A). A sagittal section shows that the cells expressing $X$ shisa2 are in the posterior portion of the paraxial mesoderm, but not in the neuroectoderm (Fig. 2 B,C). As somitogenesis commences, Xshisa-2 transcripts localize to a paraxial region, lateral to the involuting neural tube (Fig. 3B). As development proceeds, a dynamic expression pattern is observed in forming somites (Fig. 3). Its expression is stronger in the presomitic mesoderm and decreases as somites are formed. XmyoD is expressed in all myogenic cells throughout somitogenesis (Hopwood et al., 1989). Paraxial protocadherin (PAPC) expression in the PSM is restricted to the anterior halfs of somitomeres 2, 3 and 4 and is expressed uniformly from somitomere 1 to the unsegmented portion of the PSM, the tailbud domain (TBD; Kim et al., 2000). Comparing Xshisa2, XmyoDand PAPCexpression pattern one can observe that $X m y o D$ and $P A P C$ domains extend more posteriorly than the Xshisa-2 expression domain (Fig. 3
$\left.\mathrm{D}, \mathrm{H}, \mathrm{H}^{\prime}\right)$ which ends after the more posterior PAPC segmented stripe (S2) and is not expressed in the unsegmented portion of the presomitic mesoderm. A transverse section of the trunk region of a stage 27 embryo shows Xshisa-2 expression in the entire somite (Fig. 3G"). From early tailbud stages onwards Xshisa-2 is also expressed in the developing eye region. A complex expression pattern is also observed in the head at late tailbud stages, including the lens, the branchial arches (Fig. 3K'). Unlike Xshisa2, Xshisa is expressed during tailbud stages exclusively in the head region (Fig. 3I).

In this work, we report the isolation and developmental expression pattern of a second Xenopus shisa gene, Xshisa-2. The founding member of this increasing family, Xshisa, was reported to exert its activity through a novel mechanism by which both the Wnt and the FGF signaling pathways are inhibited. This activity was used by Xshisa to pattern the anterior region of the Xenopus embryo. As reported here, Xshisa-2, a closely related member of 
this family has an expression pattern opposite to that of Xshisa, at the level of the posterior mesoderm where it might be involved in formation/segmentation of the somites. The similarity to Xenopus Shisa raises the question of whether Xshisa-2 also functions as antagonists of Wnt and FGF signaling. Further biochemical and genetic analyses should help clarify the biological function of Xshisa-2 during embryonic development. Taken together, this family of genes might be employing the same strategy, inhibition of the maturation of Wnt and FGF receptors, to pattern both the anterior and the posterior regions of the Xenopus embryo.

\section{Experimental Procedures}

\section{Xenopus embryo manipulations}

Xenopus eggs were obtained from females injected with $300 \mathrm{IU}$ of human chorionic gonadotrophin (Sigma) and were fertilized in vitro. Eggs were dejellied with $2 \%$ cysteine hydrochloride $\mathrm{pH} 8$. Embryos were grown in 0.1XMBS-H (1X MBS- $\mathrm{H}=88 \mathrm{mM} \mathrm{NaCl}, 1 \mathrm{mM} \mathrm{KCl}, 2.4 \mathrm{mM} \mathrm{NaHCO}$, $0.82 \mathrm{mM}$ MgSO $4,0.41 \mathrm{mM} \mathrm{CaCl}, 0.33 \mathrm{mM} \mathrm{Ca}(\mathrm{NO} 3) 2,10 \mathrm{mM}$ HEPES $\mathrm{pH} 7.4,10 \mu \mathrm{g} / \mathrm{ml}$ streptomycin sulfate and $10 \mu \mathrm{g} / \mathrm{ml}$ penicillin) and staged according to Nieuwkoop and Faber (1967).

\section{Cloning of Xenopus shisa-2}

The EST containing the Xenopus laevis shisa-2 partial coding sequence, GenBank Acc. BJ042155, was obtained from NIBB (clone XL050n07; http://xenopus.nibb.ac.jp/).

To isolate the full length Xshisa-2 coding sequence, total RNA from late neurula (stage 18) Xenopus laevis embryos (Nieuwkoop and Faber, 1967) was isolated using Trizol $^{\circledR}$ reagent (Invitrogen) according to the manufacturer's protocol. First strand cDNA was synthesized with $\mathrm{H}$ minus M-MuLV reverse transcriptase (Fermentas) using random hexamers as primers. The following primers were used to amplify the Xshisa-2 gene product by PCR:

Forward, 5'-TTTATCGATATGTGGTTGGAGGGCTCCCCCCTG -3'; Reverse, 5'- TTTCTCGAGCTACACAGTCACGGCTGGGTACATC -3', $65^{\circ} \mathrm{C}, 25$ cycles). The PCR product was cloned into pCRII-TOPO ${ }^{\circledR}$ (Invitrogen). The sequence of Xshisa-2 cDNA described here has been deposited in GenBank under accession number DQ342341.

\section{Whole mount in situ hybridization and histology}

Single and double whole mount in situ hybridization and anti-sense probe preparation was carried out as previously described (Belo et al., 1997; Epstein et al., 1997). Digoxigenin-labeled Xshisa-2 antisense RNA probe was synthesized by linearizing the XL050n07 clone (pBS(SK)Xshisa2) using Xbal and transcribing using T7 RNA polymerase. The probe was then partially fragmented for $6 \mathrm{~min}$ at $60^{\circ} \mathrm{C}$ in hydrolysis buffer $[40 \mathrm{mM}$ $\mathrm{NaHCO}_{3}, 60 \mathrm{mM} \mathrm{Na}_{2} \mathrm{CO}_{3}, \mathrm{pH}$ 10.2] followed by sodium acetate/ethanol precipitation. To generate the fluorescein labeled $X m y o D$ and PAPC antisense RNA probes, plasmids containing XmyoD and PAPC fragments were linearized using HindIII and Xbal respectively and transcribed using T7 RNA polymerase. Stained embryos (stage 18 and above) were bleached by illumination in $1 \% \mathrm{H}_{2} \mathrm{O}_{2}, 4 \%$ formamide and $0.5 \times \mathrm{SSC} \mathrm{pH} 7.0$.

For histology, XENOPUS embryos previously in situ hybridized were fixed $\mathrm{ON}$ at $4^{\circ} \mathrm{C}$ in $4 \%$ PFA, embedded in gelatin and sectioned to $16 \mathrm{~mm}$ with a cryostat.

\section{$R T-P C R$}

Total RNA was prepared from pools of 5 embryos with Trizol ${ }^{\circledR}$ reagent (Invitrogen) according to the manufacturer's protocol. First strand CDNA primed by random hexamers was synthesized with $\mathrm{H}$ minus M-MuLV reverse transcriptase (Fermentas) and PCR was performed using standard conditions and the following sets of primers:

shisa-2-F (5'-TCCTTCTCTCAGTGCTGGCG-3') and shisa-2-R (5'-ATCGGGACTGTCCTTGTCCG-3'), 55² 25 cycles;
ODC-F (5'-CAGCTAGCTGTGGTGTGG-3') and ODC-R (5'-CAACATGGAAACTCACACC-3'), 57 C, 21 cycles.

\section{Acknowledgments}

We thank Drs E. De Robertis and R. Rupp for plasmids and $S$. Marques, A.T. Tavares and $R$. Swain for critically reading of this manuscript. A. C. Silva, M. Vitorino and M. Filipe are recipients of F.C.T. PhD fellowships. This work was supported by research grants from F.C. T. and IGC/Fundação Calouste Gulbenkian to J. A. Belo, where he is a Principal Investigator.

\section{References}

AULEHLA, A., WEHRLE, C., BRAND-SABERI, B., KEMLER, R., GOSSLER, A., KANZLER, B. and HERRMANN, B.G. (2003). Wnt3a plays a major role in the segmentation clock controlling somitogenesis. Dev. Cel/4: 395-406.

BELO, J. A., BOUWMEESTER, T., LEYNS, L., KERTESZ, N., GALLO, M., FOLLETTIE, M. AND DE ROBERTIS, E. M. (1997). Cerberus-like is a secreted factor with neutralizing activity expressed in the anterior primitive endoderm of the mouse gastrula. Mech. Dev. 68, 45-57.

BÖTTCHER, R. AND NIEHRS, C. (2005). Fibroblast Growth Factor Signaling during Early Vertebrate Development. Endocrine Reviews 26: 63-77.

CHRISTIAN, J.L. and MOON, R.T. (1993). Interactions between Xwnt-8 and Spemann organizer signaling pathways generate dorsoventral pattern in the embryonic mesoderm of Xenopus. Genes Dev. 7: 13-28.

COSSU, G. and BORELLO, U. (1999). Wnt signaling and the activation of myogenesis in mammals. EMBO J. 18: 6867-6872.

DENG, C.X., WYNSHAW-BORIS, A., SHEN, M.M., DAUGHERTY, C., ORNITZ, D.M. AND LEDER, P. (1994). Murine FGFR-1 is required for early postimplantation growth and axial organization. Genes Dev. 8: 3045-3057.

DUBRULLE, J., MCGREW, M.J. and POURQUIÉ, O. (2001). FGF signaling controls somite boundary position and regulates segmentation clock control of spatiotemporal Hox gene activation. Cel/ 106: 219-232.

EPSTEIN, M., PILLEMER, G., YELIN, R., YISRAELI, J.K. AND FAINSOD, A., (1997). Patterning of the embryo along the anterior-posterior axis: the role of the caudal genes. Development 124: 3805-3814.

FISHER, M.E., ISAACS, H.V. and POWNALL, M.E. (2002). eFGF is required for activation of XmyoD expression in the myogenic cell lineage of Xenopus laevis. Development 129: 1307-1315.

GLINKA, A., WU, W., ONICHTCHOUK, D., BLUMENSTOCK, C. AND NIEHRS, C. (1997). Head induction by simultaneous repression of Bmp and Wnt signalling in Xenopus. Nature 389: 517-519.

GLINKA, A., WU, W., DELIUS, H., MONAGHAN, A.P., BLUMENSTOCK, C. AND NIEHRS, C. (1998). Dickkopf-1 is a member of a new family of secreted proteins and functions in head induction. Nature 391: 357-362.

HOPPLER, S., BROWN, J.D. and MOON, R.T. (1996). Expression of a dominant negative Wht blocks induction of MyoD in Xenopus embryos. Genes Dev. 10: 2805-2817.

HOPWOOD, N.D., PLUCK, A. and GURDON, J.B. (1989). MyoD expression in the forming somites is an early response to mesoderm induction in Xenopus embryos. EMBO J. 8: 3409-3417.

KIM, S.H., JEN, W.C., DE ROBERTIS, E.M. AND KINTNER, C. (2000). The protocadherin PAPC establishes segmental boundaries during somitogenesis in xenopus embryos. Curr. Biol. 10:821-830.

LOGAN, C.Y. AND NUSSE, R. (2004). The Wnt Signaling Pathway in Development and Disease. Annu. Rev. Cell Dev. Biol. 20: 781-810.

MARVIN, M. J., DI ROCCO, G., GARDINER, A., BUSH, S.M. AND LASSAR, A.B. (2001). Inhibition of Wnt activity induces heart formation from posterior mesoderm. Genes Dev. 15: 316-327.

MUKHOPADHYAY, M., SHTROM, S., RODRIGUEZ-ESTEBAN, C., CHEN, L., TSUKUI, T., GOMER, L., DORWARD, D.W., GLINKA, A., GRINBERG, A., HUANG, S.P., NIEHRS, C., BELMONTE, J.C. AND WESTPHAL, H. (2001). Dickkopf1 is required for embryonic head induction and limb morphogenesis in the mouse. Dev. Cel/1, 423-434.

NIEUWKOOP, P.D. and FABER, J. (1967). Normal Table of Xenopus laevis 
(Daudin). Amsterdam, North Holland Publishing Company.

POURQUIÉ, O. (2001).Vertebrate Somitogenesis. Annu. Rev. Cell Dev. Biol. 17: 311-350.

PICCOLO, S., AGIUS, E., LEYNS, L., BHATTACHARYYA, S., GRUNZ, H., BOUWMEESTER, T. AND DE ROBERTIS, E.M. (1999). The head inducer Cerberus is a multifunctional antagonist of Nodal, BMP and Wnt signals. Nature 397: 707-710.

SCHNEIDER, V.A. AND MERCOLA M.(2001). Wht antagonism initiates cardiogenesis in Xenopus laevis. Genes Dev. 15:304-315.

SILVA, A.C., FILIPE, M., KUERNER, K.-M., STEINBEISSER, H. AND BELO, J.A. (2003) Endogenous Cerberus activity is required for anterior head specification in Xenopus. Development, 130: 4943-4953.

SUN, X., MEYERS, E.N., LEWANDOSKI, M. AND MARTIN, G.R. (1999). Targeted disruption of Fgf8 causes failure of cell migration in the gastrulating mouse embryo. Genes Dev. 13:1834-1846.
TAKADA, S., STARK, K.L., SHEA, M.J., VASSILEVA, G., MCMAHON, J.A. and MCMAHON, A.P. (1994). Wnt-3a regulates somite and tailbud formation in the mouse embryo. Genes Dev. 8: 174-189.

YAMAGUCHI, T.P., HARPAL, K., HENKEMEYER, M. AND ROSSANT, J. (1994). fgfr-1 is required for embryonic growth and mesodermal patterning during mouse gastrulation. Genes Dev. 8:3032-3044.

YAMAMOTO, A., NAGANO, T., TAKEHARA, S., HIBI, M. AND AIZAWA, S. (2005). Shisa promotes head formation through the inhibition of receptor protein maturation for the caudalizing factors, Wnt and FGF. Cel/120: 223-235.

Received: January 2006 Reviewed by Referees: February 2006 Modified by Authors and Accepted for Publication: February 2006 Published Online: March 2006 